\title{
Carol Altman Bromberg, Nicholas Sims-Williams, Ursula Sims-Williams. Iranian and Zoroastrian Studies in Honor of Prods Oktor Skjorvø
}

\section{Philip Huyse}

\section{(2) OpenEdition}

\section{Journals}

Édition électronique

URL : http://journals.openedition.org/abstractairanica/41951

DOI : 10.4000/abstractairanica.41951

ISSN : 1961-960X

Éditeur :

CNRS (UMR 7528 Mondes iraniens et indiens), Éditions de l'IFRI

Référence électronique

Philip Huyse, « Carol Altman Bromberg, Nicholas Sims-Williams, Ursula Sims-Williams. Iranian and Zoroastrian Studies in Honor of Prods Oktor Skjærvø », Abstracta Iranica [En ligne], Volume 34-35-36 | 2017, document 3, mis en ligne le 30 juillet 2017, consulté le 27 septembre 2020. URL : http:// journals.openedition.org/abstractairanica/41951; DOI : https://doi.org/10.4000/abstractairanica. 41951

Ce document a été généré automatiquement le 27 septembre 2020

Tous droits réservés 


\title{
Carol Altman Bromberg, Nicholas Sims-Williams, Ursula Sims- Williams. Iranian and Zoroastrian Studies in Honor of Prods Oktor Skjœrvø
}

\author{
Philip Huyse
}

\section{RÉFÉRENCE}

Carol Altman Bromberg, Nicholas Sims-Williams, Ursula Sims-Williams. Iranian and Zoroastrian Studies in Honor of Prods Oktor Skjervø. Bloomfield Hills, MI: Bulletin of the Asia Institute, published with the assistance of the Neil Kreitman Foundation (U.K.), 2005 [2009], viii + 238 p. (Bulletin of the Asia Institute, vol. 19)

1 Comme le rappelle à juste titre Ursula Sims-Williams dans son portrait amical en guise d'introduction (p. 1-4), le savant norvégien Prods Oktor Skjærvø, « Aga Khan Professor of Iranian Studies " à l'Université de Harvard, a été et continue d'être un chercheur prolifique. Par sa production scientifique, il couvre en outre une remarquable diversité de langues iraniennes dans la longue durée (iranien ancien, moyen et moderne), ainsi que de religions (zoroastrisme, manichéisme et judaïsme babylonien rabbinique). Il est par ailleurs particulièrement généreux de son savoir au bénéfice de ses étudiants, ayant mis à la disposition de tous le matériel de ses cours dans plusieurs domaines sur son site web personnel (http://www.fas.harvard.edu/ iranian/).

Le volume 19 de la revue "Bulletin of the Asia Institute" comprend vingt-huit contributions exquises en son honneur, que voici : Duan Qing, “Mullberry' in Khotanese: A New Khotanese Loan Deed in the Hetian Museum" (p. 5-14). Yaakov Elman, "The Other in the Mirror: Iranians and Jews View One Another. Questions of Identity, Conversion and Exogamy in the Fifth-Century Iranian Empire. Part One" (p. 15-25 [Part Two is to be published in BAI 20, 2010]). Richard N. Frye, "Church and State 
in Iranian History" (p. 27-28). Rika Gyselen, "Vahrām III (293) and the Rock Relief of Naqsh-i Rustam II: A Contribution to the Iconography of Sasanian Crown Princes in the Third Century" (p. 29-36). Valerie Hansen, "The Tribute Trade with Khotan in Light of Materials Found at the Dunhuang Library Cave" (p. 37-46). Prudence O. Harper, "From Earth to Heaven: Speculations on the Significance of the Form of the Achaemenid Censer" (p. 47-56). Almut Hintze, "The Cow that Came from the Moon: The Avestan Expression māh gaociӨra-" (p. 57-66). Stephanie W. Jamison, "Poetic Self-Reference in the Rig Veda and the Persona of Zarathustra" (p. 67-70). Jean Kellens et Philippe Swennen, "Le sacrifice et la nature humaine" (p. 71-76). Hiroshi Kumamoto, "Paul Pelliot and the Deśanā-parivarta of the Suvarnabhāsa-sūtra" (p. 77-82). Judith A. Lerner, “An Alan Seal" (p. 83-89). Maria Macuch, "The Hērbedestān as a Legal Source: A Section on the Inheritance of a Convert to Zoroastrianism" (p. 91-102). Mauro Maggi, "Annotations on the Book of Zambasta, II: Khotanese mamkyā-" (p. 103-109). Antonio Panaino, "Sheep, Wheat and Wine: An Achaemenian Antecedent of the Sasanian Sacrifices pad ruwān" (p. 111-18). Rong Xinjiang, "The Name of the So-Called 'Tumshuqese' Language” (p. 119-27). James R. Russell, “The Demon Weed” (p. 129-32). Lore Sander, "Remarks on the Formal Brāhmī Script from the Southern Silk Route" (p. 133-44). Martin Schwartz, "Apollo and Khshthrapati, the Median Nergal, at Xanthos" (p. 145-50). Shai Secunda, "Studying with a Magus / Like Giving a Tongue to a Wolf" (p. 151-57). Shaul Shaked, "Aramaic Loan-Words in Middle Persian" (p. 159-68). Rahim Shayegan, "Nugae Epigraphicae" (p. 169-79). Daniel Jensen Sheffield, "The Wizirgerd $i$ Dēnig and the Evil Spirit: Questions of Authenticity in Post-Classical Zoroastrianism" (p. 181-89). Nicholas Sims-Williams, "Before the Quarrel: A Bactrian Purchase Contract" (p. 191-98). Ursula Sims-Williams, "The Strange Story of Samuel Guise: An 18th-Century Collection of Zoroastrian Manuscripts" (p. 199-209). Werner Sundermann, "The Emperor's New Clothes" (p. 211-14), Yuhan Sohrab-Dinshaw Vevaina, "Resurrecting the Resurrection: Eschatology and Exegesis in Late Antique Zoroastrianism" (p. 215-23). Dieter Weber, "A Pahlavi Papyrus from Islamic Times" (p. 225-31). Yutaka Yoshida, “Viśa' Śūra's Corpse Discovered” (p. 233-38).

\section{AUTEURS}

\section{PHILIP HUYSE}

EPHE 